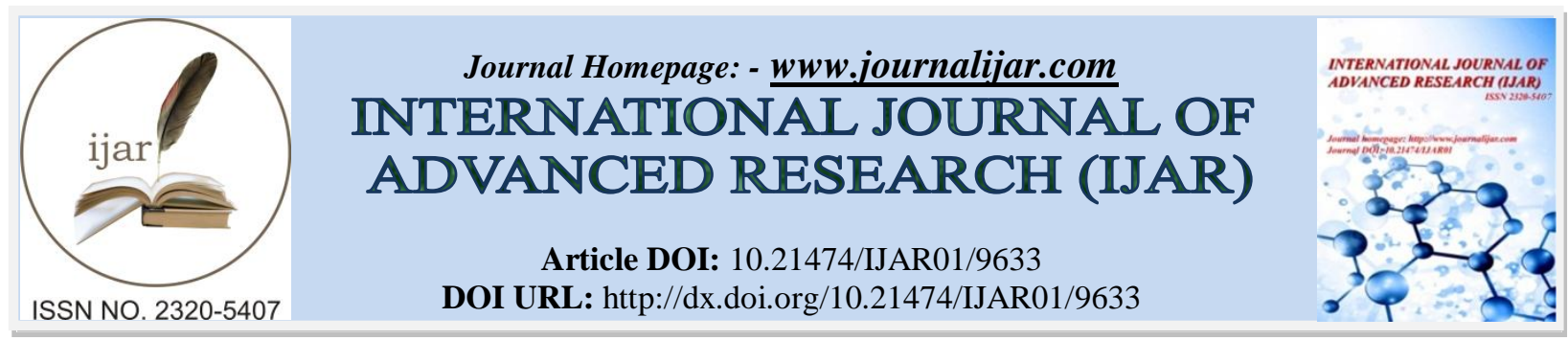

RESEARCH ARTICLE

\title{
ANALYSIS OF REGION POTENCY AND TYPOLOGY OF BEEF CATTLE LIVESTOCK AT GORONTALO REGENCY.
}

\author{
La Ode Sahara ${ }^{1}$, Z. Fanani ${ }^{2}$, Ba. Nugroho ${ }^{2}$, Irfan H. Djunaidi². \\ 1. Postgraduate students of Animal Science, Brawijaya University. \\ 2. Lecturer of Animal Science, Brawijaya University.
}

\section{Manuscript Info}

Manuscript History

Received: 02 July 2019

Final Accepted: 04 August 2019

Published: September 2019

Key words:-

Beef Cattle, Livestock, Region Potency, Typology.

\begin{abstract}
This study aimed to analyze the structure and distribution, growth rates, population densities and typology of beef cattle livestock. Conducted in Gorontalo Regency from June to August 2018. Quantitative research methods were used to obtain data and solve existing problems. The results showed that the population of beef cattle in Gorontalo Regency reached to 65,539 $\mathrm{AU}$ with an average growth of $4.27 \%$ per year. Economic Density of beef cattle population 166 AU/1000 (Solid), Regional Density $31 \mathrm{AU} / \mathrm{km}^{2}$ (Solid), and Farm Density $0.53 \mathrm{AU} / \mathrm{ha}$ (Medium). Ownership of beef cattle is high with a limited area, but the area of farming is still supportive. Beef cattle development can be directed at intensive or semi-intensive breeding patterns through the integration of rice plant, maize and sugar cane systems with beef cattle (Crop Livestock System). The development area has a different typology of livestock. The eastern and central regions develop Balinese cattle in a semi-intensive and extensive manner, while the western regions develop more varied beef cattle with intensive breeding patterns.
\end{abstract}

Copy Right, IJAR, 2019,. All rights reserved.

\section{Introduction:-}

Beef cattle development in Gorontalo Regency has a bright prospect because it is supported by the potential of the region in the form of population and feed resources, both forage for natural food and agricultural waste as well as concentrates. This situation is supported by consumer needs for beef which continues to increase every year with increasing population.

Gorontalo Regency has the largest beef cattle population in Gorontalo Province. In 2017 it was recorded to have reached 85.6 thousand beef cattles (Gorontalo Regency BPS, 2018) or 37.6\% of the population of Gorontalo Province which had reached 227.4 thousand heads (DG PKH, 2018). The population is still very small compared to other regions that have become centers of beef cattle producers; however there is still a chance to be increased so that they become centers of beef cattle producers. The development of beef cattle in Gorontalo Regency has been carried out for a long time but has not been as expected because of the reality on the ground; farmers have not been able to utilize the existing potential to increase beef cattle population.

Various problems are faced in the development of beef cattle, but all of them start from the development of beef cattle which are still based on traditional farming patterns. Beef cattle business has not been used as a commercial

Corresponding Author:-La ode sahara.

Address:-Postgraduate students of animal science, brawijaya university. 
business and is still just a side business of agricultural activities. The traditional beef cattle business is also characterized by minimal utilization of available resources making it difficult to achieve the target of increasing livestock population.

\section{Research purposes:-}

Based on the description of the existing problems, this study was conducted with the aim of analyzing population structure and distribution, population growth rates, and population densities and typology of beef cattle farms in Gorontalo Regency.

\section{Research Methods:-}

\section{Location and Time: -}

This research was carried out in the administrative area of Gorontalo Regency. The location was chosen purposively by considering the potential possessed, namely: 1) the location of beef cattle commodity development and 2) the largest beef cattle population in Gorontalo Province which reached 37\%. This research was conducted for 3 months, starting from June to August 2018.

\section{Research methods:-}

Quantitative research methods are used to obtain data and solve existing problems. The data used in this study are the regional potential and typology of beef cattle livestock. Regional potential data, namely population, area and farm area are secondary data sourced from related agencies, namely: Statistics Indonesia, Population and Civil Registry, Agriculture and Animal Husbandry Services. Livestock typology data, which are farming patterns and livestock business, are primary data sourced from farmer respondents. Secondary data collection is done through documentation, while primary data is collected through questionnaires.

Research on regional potential covers 19 regencys in Gorontalo Regency. The typology of beef cattle farms is based on the division of development areas according to the geographical location of Gorontalo Regency which stretches from east to west, namely:

1. Eastern region; Lands around Lake Limboto, including the regencys of Batudaa, Batudaa Beach, Limboto, West Limboto, Tabongo, Telaga, Telaga Biru, Telaga Jaya, and Tilango.

2. Middle region; Lands between eastern and western regions with dominant dry land topography, including the regencys of Bilato, Biluhu, Bongomeme, Dungaliyo, Pulubala, and Tibawa.

3. West region; Lands around the Paguyaman River, including the regencys of Asparaga, Boliyohuto, Mootilango and Tolangohula.

Livestock typology research is carried out by taking several regencys as sample locations. For each development area, 2 regencys were selected, representing the following criteria: 1) having a beef cattle population of at least $5 \%$ of the population of the regency, and 2) having a minimum of 20 groups of beef cattle farmers. The selected regencys in the eastern region are Limboto and West Limboto, the central region are Bongomeme and Pulubala, and the western region, namely Boliyohuto and Tolangohula.

\section{Population and Sample: -}

The populations in this study were all beef cattle farmers in the group of farmers in 6 regencys, namely 2,170 people. Based on the existing population, the minimum sample size is known using the Slovin formula below:

Where:

$$
\mathrm{n}=\frac{\mathrm{N}}{1+\mathrm{N}(\mathrm{e})^{2}}
$$

$\mathrm{n}=$ Number of samples

$\mathrm{N}=$ Number of population

$\mathrm{e}=$ Error margin $(0.1)$

Based on calculations obtained a total sample of 95 people. Samples in each regency are then determined proportionally. The sample or respondent is determined through purposive sampling, namely farmers who are actively conducting beef cattle cultivation activities and are documented in the Gorontalo Regency Animal Husbandry and Animal Health Service. The sample composition of each regency, namely: Limboto 15 people, West Limboto 15 people, Bongomeme 19 people, Pulubala 13 people, Boliyohuto 14 people, and Tolangohula 19 people. 


\section{Data Analysis: -}

Analysis of Population Structure and Distribution

The composition of livestock population structure according to age of livestock is calculated using the conversion value of livestock, i.e. the percentage of young, young and mature livestock to the livestock population. The number of livestock is calculated based on the population structure multiplied by the standard value of the animal unit. Livestock conversion value (\%) of mature beef cattle (56.33), young (26.68), and calves (16.99). Animal Unit (AU) standards mature beef cattle (1.00), young (0.60), and calves (0.25) (Krisnan and Ginting, 2011).

\section{Analysis of Population Growth Rate}

The parameter used in determining the growth rate is the display of livestock population within a certain period. This study uses beef cattle population data for each regency in Gorontalo Regency in the last 3 years of 2015 - 2017. Time series data is used to avoid annual bias. The population variables analyzed are the population at the beginning of the year (Initial Value) and at the end of the year (Final Value). Population growth is calculated by function:

Where:

$$
\mathrm{GR}=\frac{\mathrm{FV}-\mathrm{IV}}{\mathrm{IV}} \times 100 \%
$$

GR $=$ Growth Rate $(\%)$

$\mathrm{FV}=$ Final Value

IV = Initial Value

\section{Population Density Analysis}

Livestock population density consists of 3 types, they are economic density, regional density, and farming density. The livestock population density criteria indicate the extent of livestock distribution in an area (DG of Animal Husbandry, 2000).

Economic Density (ED) is calculated based on the number of beef cattle population (AU) per 1000 inhabitants. The criteria are: Very Solid (> 300), Solid (> 100 - 300), Medium (50 - 100), and Rare (<50).

Regional Density (RD) is calculated based on the number of beef cattle population (AU) per area (km2). The criteria are: Very Solid (> 50), Solid (> $20-50)$, Medium (10 - 20), and Rare $(<10)$.

Farm Density (FD) is calculated based on the number of beef cattle population (AU) per farm area (ha). The criteria are: Very Solid (> 2), Solid (> 1-2), Medium (0.25-1), and Rare $(<0.25)$.

\section{Livestock Typology}

The data collected is processed through the data tabulation process and displayed in the form of percentage figures.

\section{Research Result And Discussion:-}

Population Structure and Distribution

The actual condition of livestock development in an area is reflected in the structure and distribution of its population, called calves, young and mature livestock which are displayed in the form of Animal Units (AU). A description of the structure and distribution of beef cattle population in Gorontalo Regency can be seen in Table 1 .

Table 1:-Structure and Distribution of Beef Cattle Population in Gorontalo Regency.

\begin{tabular}{|r|l|r|r|r|r|}
\hline \multirow{2}{*}{ No Regency } & \multicolumn{2}{|c|}{ Beef Cattle Population Structure (AU) } & \multirow{2}{*}{ Total (AU) } \\
\cline { 3 - 6 } & & Calves & \multicolumn{1}{c|}{ Young } & \multicolumn{2}{c|}{ Mature } \\
\hline 1 & Asparaga & 184 & 693 & 3,437 & 1,072 \\
\hline 2 & Batudaa & 81 & 305 & 880 & 1,457 \\
\hline 3 & Batudaa Pantai & 66 & 250 & 1,279 & 7,196 \\
\hline 4 & Bilato & 96 & 363 & 3,580 & 1,738 \\
\hline 5 & Biluhu & 56 & 213 & 3,445 & 4,018 \\
\hline 6 & Boliyohuto & 270 & 1,017 & 2,819 & 4,683 \\
\hline 7 & Bongomeme & 260 & 979 & 2,688 & 3,833 \\
\hline 8 & Dungaliyo & 213 & 801 & 764 & 3,655 \\
\hline 9 & Limboto & 203 & & & \\
\hline
\end{tabular}




\begin{tabular}{|r|l|r|r|r|r|}
\hline 10 & Limboto Barat & 269 & 1,015 & 3,570 & 4,854 \\
\hline 11 & Mootilango & 351 & 1,322 & 4,652 & 6,324 \\
\hline 12 & Pulubala & 366 & 1,380 & 4,855 & 6,600 \\
\hline 13 & Tabongo & 188 & 710 & 2,499 & 3,397 \\
\hline 14 & Telaga & 104 & 393 & 1,383 & 1,880 \\
\hline 15 & Telaga Biru & 157 & 592 & 2,082 & 2,831 \\
\hline 16 & Telaga Jaya & 59 & 224 & 789 & 1,072 \\
\hline 17 & Tibawa & 369 & 1,392 & 4,897 & 6,658 \\
\hline 18 & Tilango & 57 & 216 & 759 & 1,032 \\
\hline 19 & Tolangohula & 284 & 1,072 & 3,772 & 5,129 \\
\hline & Gorontalo Regency & $\mathbf{3 , 6 3 5}$ & $\mathbf{1 3 , 6 9 9}$ & $\mathbf{4 8 , 2 0 5}$ & $\mathbf{6 5 , 5 3 9}$ \\
\hline
\end{tabular}

Source: Processed research data, 2018.

The result of the analysis in Table 1 shows that the beef cattle population in Gorontalo Regency has reached 65 thousand $\mathrm{AU}$ with the composition of the structure of mature livestock population $73.5 \%$, young cattle $20.9 \%$, and young cattle 5.6\%. Mature livestock population is higher so that efforts are needed to increase the population of young and young cattle. Efforts can be made through improving the breeding infrastructure and quality of beef cattle reproduction. Suryana (2009) states that the problems often faced in the development of beef cattle, namely: 1) low reproductive efficiency of livestock, 2) continuity of availability and low quality of feed,3) utilization of agricultural and agro-industrial waste as feed is not optimal, and 4 ) going business is less attractive to investors because it is economically less profitable. Based on population distribution it is known that high beef cattle population or more than 6 thousand AU are found in 3 regencys, such as: Tibawa, Pulubala, and Mootilango.

The dominant type of beef cattle developed by farmers in Gorontalo Regency is Bali cattle because in general the Province of Gorontalo is a spreading area of Bali cattle. Based on the map of the area of local cattle breeding sources in Indonesia, Gorontalo Province is one of 18 provinces which are the source of local cattle breeds and includes 7 provinces which are only sources of Bali cattle breeds, namely Bali, West Nusa Tenggara, South Sulawesi, Southeast Sulawesi, West Sulawesi, Gorontalo and South Kalimantan (DG PKH, 2018).

Simatupang, et al (2004) stated that traditional farms are more likely to develop beef cattle with local breeds. Local cattle that are farmed by farmers have many advantages, namely the ability to consume low-quality feed, good reproduction, and good adaptation to the tropical environment. These advantages can be utilized optimally for the development of Bali cattle through improved management of cultivation, ranging from feeding and drinking water, reproduction and production, housing, to handling animal health.

\section{Population Growth}

The development of livestock population in an area can be seen from the percentage of population growth over a period of time. Percentage growth of beef cattle population in Gorontalo Regency 2015 - 2017 can be seen in the following diagram.

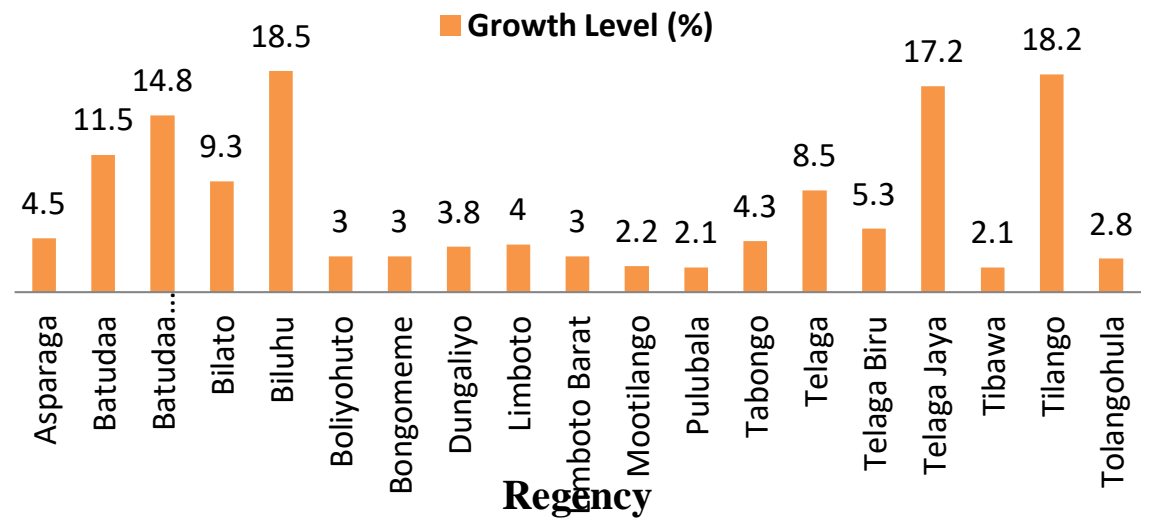

The Growth of Beef Cattle Population Diagram in Gorontalo Regency

Source: Data processed from research results, 2018 
Based on the analysis of population growth in the diagram, it is known that the population growth of beef cattle in each regency in Gorontalo Regency is uneven with a range of $2 \%$ to $18 \%$ per year. The regency with the highest average population growth is Biluhu and the lowest is Tibawa. An interesting phenomenon can be seen in the population growth of Batudaa, Telaga Jaya and Tilango regencys, which is quite high at above $11 \%$, but has limited land so that these three regions are no longer possible to increase population through large-scale livestock intake.

The target of animal husbandry development in Gorontalo Regency is measured by several indicators, one of which is the growth of livestock population. Ruminant livestock population growth to be achieved each year is $4 \%$ (Gorontalo Regency PKH Service, 2016). The analysis shows that the average growth of beef cattle population in Gorontalo Regency is $4.3 \%$ per year. This population growth has exceeded the target of the local government, but 8 regencys or $42 \%$ of beef cattle development areas are still below $4 \%$ per year. This population growth still needs to be increased because the needs or consumer demand for beef cattle continues to increase every year as the population grows.

There are various factors that inhibit the growth and development of beef cattle populations. This condition is a big challenge in developing beef cattle in Gorontalo Regency. Syamsu, et al (2003) stated several factors that inhibited the development of beef cattle, namely: 1) diminishing grazing areas, 2) low quality of resources, 3) technological adoption is still low, and 4) access to capital is still difficult. Many factors inhibit the growth and development of beef cattle, but all of them start from community farms that are still managed traditionally. Traditional farming is generally characterized by farmers with a low level of education and lack of capital to develop their businesses so that livestock business is carried out without management application and cultivation technology.

Low beef cattle population growth can affect the availability of meat, both locally and nationally. Domestic beef production has not been able to meet existing needs because of population growth and livestock productivity that is still low. Kariyasa (2005) explains that beef cattle populations are low, partly because most of the animals are raised by farmers with limited land and capital. This condition makes it difficult for farmers to increase livestock ownership and advance their business. Population growth can increase if the problems encountered can be resolved through: 1) improvement of feed logistics; starting from the supply, storage, processing, preservation, until feeding, 2) the application of cultivation technology; starting from feed technology, reproduction to housing, and 3) introduction of business management to farmer groups through mentoring programs.

\section{Livestock Population Density}

The economic density of the livestock population illustrates the impact of livestock on the economy of the community in the production center area. Regional density describes the proportion of the area per unit of animal owned. The density of farming illustrates the proportion of land area for farming per unit of livestock owned. The population density of beef cattle in Gorontalo Regency can be seen in Table 2.

Table 2:-Value and Density Criteria for Beef Cattle Population in Gorontalo Regency

\begin{tabular}{|c|l|c|l|c|l|c|l|}
\hline No & \multicolumn{1}{|c|}{ Regency } & $\begin{array}{c}\text { ED } \\
(\mathbf{A U / 1 0 0 0})\end{array}$ & Criteria & $\begin{array}{c}\mathbf{R D} \\
\left(\mathbf{A U} / \mathbf{k m}^{\mathbf{2}}\right)\end{array}$ & Criteria & $\begin{array}{c}\text { FD } \\
(\mathbf{A U} / \mathbf{h a})\end{array}$ & Criteria \\
\hline 1 & Asparaga & 241 & Solid & 8 & Rare & 0.22 & Rare \\
\hline 2 & Batudaa & 101 & Solid & 44 & Solid & 0.56 & Medium \\
\hline 3 & Batudaa Pantai & 100 & Medium & 19 & Medium & 0.46 & Medium \\
\hline 4 & Bilato & 176 & Solid & 15 & Medium & 0.46 & Medium \\
\hline 5 & Biluhu & 118 & Solid & 13 & Medium & 0.27 & Medium \\
\hline 6 & Boliyohuto & 288 & Solid & 80 & Very Solid & 1.11 & Solid \\
\hline 7 & Bongomeme & 242 & Solid & 32 & Solid & 0.40 & Medium \\
\hline 8 & Dungaliyo & 220 & Solid & 82 & Very Solid & 0.95 & Medium \\
\hline 9 & Limboto & 74 & Medium & 35 & Solid & 0.55 & Medium \\
\hline 10 & Limboto Barat & 190 & Solid & 61 & Very Solid & 0.94 & Medium \\
\hline 11 & Mootilango & 324 & Very Solid & 30 & Solid & 0.64 & Medium \\
\hline 12 & Pulubala & 253 & Solid & 27 & Solid & 0.38 & Medium \\
\hline 13 & Tabongo & 181 & Solid & 62 & Very Solid & 0.67 & Medium \\
\hline 14 & Telaga & 83 & Medium & 67 & Very Solid & 1.06 & Solid \\
\hline 15 & Telaga Biru & 96 & Medium & 26 & Solid & 0.57 & Medium \\
\hline
\end{tabular}




\begin{tabular}{|l|l|c|l|c|l|c|l|}
\hline 16 & Telaga Jaya & 88 & Medium & 167 & Very Solid & 2.94 & Very Solid \\
\hline 17 & Tibawa & 162 & Solid & 46 & Solid & 0.60 & Medium \\
\hline 18 & Tilango & 69 & Medium & 178 & Very Solid & 2.44 & Very Solid \\
\hline 19 & Tolangohula & 226 & Solid & 30 & Solid & 0.42 & Medium \\
\hline & Regency & $\mathbf{1 6 6}$ & Solid & $\mathbf{3 1}$ & Solid & $\mathbf{0 . 5 3}$ & Medium \\
\hline
\end{tabular}

Source: Processed research data, 2018.

Based on the results of the analysis in Table 2, it is known that the economic density value of beef cattle population in Gorontalo Regency is 166 AU/1000 inhabitants with dense criteria. There are 12 regencys or $63 \%$ of beef cattle development areas that have economic density with Solid criteria and 6 regencys with Medium criteria. This shows the high level of beef cattle ownership, also illustrating that the distribution of beef cattle has a positive impact and is a driving force for the community's economy.

Mootilango Regency has the highest economic density value with Very Solid criteria, i.e. there are 324 AU of beef cattle per 1000 inhabitants. This regency has a very high level of ownership and beef cattle population. This situation indicates that beef cattle commodity has become one of the main sources of income for the community.

The value of the population density of beef cattle in Gorontalo Regency is $31 \mathrm{AU} / \mathrm{km}^{2}$ with Solid criteria. It is also known that 7 regencys or 37\% of beef cattle development areas have an area density with very Solid criteria and 8 regencys or $42 \%$ with Solid criteria. Regencys that have a density of regions with sparse criteria are Asparaga and Medium criteria, namely Beach Batuda, Bilato, and Biluhu. This shows that most regencys in Gorontalo Regency already have limited area for developing beef cattle.

The limited area of development has led to high competition between beef cattle and the population in resource use. Competition takes place on the use of land resources, which are used as agricultural food-producing land or forage land. Extensive development of beef cattle has been limited so that the pattern of raising beef cattle can be directed to intensive or semi-intensive patterns.

The value of population density of beef cattle population in Gorontalo Regency is $0.53 \mathrm{AU} / \mathrm{ha}$ with moderate criteria. Regencys that have a density of farming with very Solid criteria are Telaga Jaya and Tilango, while the regencys with Solid criteria are Boliyohuto and Telaga. There are 14 regencys or $74 \%$ of beef cattle development areas that have a density of farming with medium criteria and regencys with rarely criteria only Asparaga. This situation shows that most of the regencys in Gorontalo Regency have the carrying capacity of farming land for beef cattle development.

The potential carrying capacity of large farms can be utilized for the development of beef cattle through the synergy between farming and beef cattle business. This development model is known as the Crop Livestock System. Gorontalo Regency is an area of agricultural development for rice plant, maize, soybean, sugar cane and beef cattle. This potential can support the development of integrated systems of rice plant with beef cattle, maize with beef cattle, and beef cattle with sugar cane (Livestock Sugarcane Integration System).

The system of integration of rice plant, maize and sugar cane with beef cattle has a multiplier effect for livestock, farmers, and the environment. Beef cattle get enough food from agricultural waste, increase farmers' income, and prevent environmental damage from burning agricultural waste. Bad habits of burning agricultural waste can lead to land degradation, environmental pollution, damage to ecosystems, and loss of biodiversity.

Nurhayati and Widiawati (2017) explained that agriculture and animal husbandry activities often become the public spotlight as one of the biggest contributors to Greenhouse Gas emissions, such as Carbon Dioxide $\left(\mathrm{CO}_{2}\right)$ and Methane $\left(\mathrm{CH}_{4}\right)$ which causes global warming and climate change. The development of beef cattle through the Crop Livestock System model can minimize the impact of environmental damage caused by the activity of burning agricultural waste.

\section{Typology of Beef Cattle Livestocks}

The development of beef cattle in an area is influenced by the typology of cultivation and livestock business. A description of the typology of beef cattle farming and business in Gorontalo Regency is presented in Table 3. 
Table 3:-Typology of beef cattle livestocks in Gorontalo Regency

\begin{tabular}{|c|c|c|c|c|}
\hline \multirow[t]{2}{*}{ No. } & \multirow[t]{2}{*}{ Cultivation Aspects } & \multicolumn{3}{|c|}{ Respondent (\%) } \\
\hline & & Eastern Region & Central Region & Western Region \\
\hline \multirow[t]{3}{*}{1} & Type of livestock & & & \\
\hline & - Bali cattle & 100 & 100 & 88 \\
\hline & - Other types of cattle & - & - & 12 \\
\hline \multirow[t]{5}{*}{2} & Seed sources & & & \\
\hline & - Family inheritance & 7 & - & 3 \\
\hline & - Purchase & 17 & 16 & 64 \\
\hline & - Government assistance & 73 & 75 & 21 \\
\hline & - Cooperation & 3 & 9 & 12 \\
\hline \multirow[t]{4}{*}{3} & Maintenance patterns & & & \\
\hline & - Extensive & 30 & 53 & - \\
\hline & - Semi intensive & 70 & 47 & 6 \\
\hline & - Intensive & - & - & 94 \\
\hline \multirow[t]{4}{*}{4} & Scale enterprises & & & \\
\hline & - Side by side & 97 & 97 & 82 \\
\hline & - Mixed & - & - & 15 \\
\hline & - Main & 3 & 3 & 3 \\
\hline
\end{tabular}

Source: Processed research data, 2018.

Table 3 shows that groups of beef cattle farmers in the eastern and central regions are cultivating Bali cattle. This reality is in line with the map of the local cattle breeding source area in Indonesia which shows that Gorontalo Province is one of 7 provinces which are only the source areas of Bali cattle breeding (DG PKH, 2018). The types of beef cattle cultivated in the western region are more varied than other regions. The analysis shows that $88 \%$ of farmers breed Bali cattle and $12 \%$ breed other types of cattle, such as Hybrid of Ongole, Simental and Limousin.

Based on the source of beef cattle breeds that are cultivated it is known that more than $70 \%$ of farmers in the eastern and middle regions are getting their seeds from government assistance. Seed sources in the western region are more varied, with $64 \%$ of farmers obtaining livestock breeds from purchases. This situation shows that the initiative and motivation of farmers to raise cattle in the western region is higher than other regions so that this region has a good culture of livestock farming for beef cattle development.

Beef cattle cultivation system consists of several maintenance patterns, such as: 1) intensive; livestock raising kept in captivity throughout the day, 2) semi-intensive; raising livestock with caged at night and daytime grazing, and 3) extensive; raising livestock in the pasture with no stables. Farmers in the beef cattle development area apply a different breeding pattern: $94 \%$ of farmers in the western region apply intensive patterns, $70 \%$ in the semi-intensive eastern region, and 53\% extensive in the middle region. Achmadi (2010) states that intensive maintenance patterns are more economical than extensive, which requires large areas for grazing.

The description of cultivation patterns shows that the three areas of beef cattle development have different typologies. In general, the types of beef cattle developed in the eastern region are Balinese cattle with a semiintensive maintenance pattern. Farmers in the central region also develop Bali cattle but with extensive breeding patterns. Unlike the eastern and central regions, the types of beef cattle developed in the western region are more varied with intensive breeding patterns. The typology display of different aquaculture systems in each region can be an input for policy maker.

Livestock business scale shows the development of livestock business in an area. Based on the scale of livestock business, it is known that $97 \%$ of farmers in the eastern and central regions and $82 \%$ of farmers in the western region still make beef cattle business a side business of agricultural business. Side businesses are characterized by a small number of livestock ownership and livestock farming activities are only interrupts between farming activities.

Based on the type of business scale, Suryana (2009) states that livestock business consists of 4 types, namely: 1) side businesses; livestock business becomes a side business of an agricultural business with an income level of less than $30 \%, 2)$ a mixed business; livestock business has become a branch of business that coexists with agricultural 
business with an income level of $30-70 \%, 3$ ) main business; livestock business has become the main business with $70-100 \%$ income level.

The development of beef cattle can be done by encouraging farmers to increase their livestock ownership so that the scale of their business increases to a mixed business that gives farmers the opportunity to increase their income. Beef cattle business in the western region is more developed than other regions because $15 \%$ of farmers have run mixed businesses so that livestock business has become a business branch that receives the same attention as agricultural business.

\section{Conclusions And Suggestions:-}

Based on the description of the results and discussion it can be concluded:

1. The structure of the mature beef cattle population is higher so that efforts are needed to increase the population of young cattle and young cattle through improving the breeding infrastructure and the quality of beef cattle reproduction.

2. Beef cattle population growth has exceeded the Gorontalo Regency Government's target, but it has not been evenly distributed and $42 \%$ of the development area is still below the $4 \%$ growth target per year so it must still be increased to meet consumer needs for beef.

3. Beef cattle population in Gorontalo Regency has economic density with Solid criteria, regional density with Solid criteria, and farm density with Medium criteria which indicates the distribution of beef cattle to be a driver of the community's economy with a high level of beef cattle ownership and limited area. However, the size of the farming land is still supportive so that the development of beef cattle can be directed to the pattern of intensive or semi-intensive maintenance through the Crop Livestock System model.

4. The area of beef cattle development has a different typology; the eastern region develops semi-intensive Balinese cattle, the middle region develops extensive Balinese cattle, and the western region develops more varied beef cattle with intensive breeding patterns.

\section{Bibliography:-}

1. Achmadi, J. (2010). Pengembangan Pakan Ternak Ruminansia: Menggagas Lumbung Pakan Berbasis Hasil Samping Tanaman Pangan. Makalah Forum Apresiasi Budidaya Ternak Ruminansia di Direktorat Jenderal Peternakan dan Kesehatan Hewan, Yogyakarta, Indonesia. 14-15 Desember 2010.

2. Badan Pusat Statistik (BPS) Kabupaten Gorontalo (2018). Kabupaten Gorontalo dalam Angka 2018. Limboto, Indonesia.

3. Dinas Peternakan dan Kesehatan Hewan (PKH) Kabupaten Gorontalo (2016). Rencana Strategis Tahun 2016 2021. Limboto, Indonesia.

4. Direktorat Jenderal Peternakan (Ditjennak) (2000). Petunjuk Teknis Identifikasi dan Analisis Potensi Wilayah Pengembangan Peternakan. Jakarta, Indonesia.

5. Direktorat Jenderal Peternakan dan Kesehatan Hewan (Ditjen PKH) (2018). Statistik Peternakan dan Kesehatan Hewan 2018. Jakarta, Indonesia.

6. Kariyasa, K. (2005). Sistem Integrasi Tanaman-Ternak dalam Perspektif Reorientasi Kebijakan Subsidi Pupuk dan Peningkatan Pendapatan petani. Jurnal Analisis Kebijakan Pertanian. Vol. 2, No. 1, 2005, hal. 68-80.

7. Krisnan, R. dan Ginting, S.P. (2011). Analisis Potensi Pengembangan Kambing Unggul Berdasarkan Ketersediaan Sumber Pakan di Sumatera Utara: Kasus di Kabupaten Simalungun. Prosiding Workshop Nasional Diversifikasi Pangan Daging Ruminansia Kecil. 2011, hal. 127-137.

8. Nurhayati, I.S. dan Widiawati, Y. (2017). Emisi Gas Rumah Kaca dari Peternakan di Pulau Jawa yang dihitung dengan Metode Tier-1 IPCC". Prosiding Seminar Nasional Teknologi Peternakan dan Veteriner di Puslitbangnak-Balitbangtan, Bogor, Indonesia. 2017, hal. 292-300.

9. Simatupang, P., Syafa'at, N., dan Hadi, P.U. (2004). Arah dan Kebijakan Pengembangan Agribisnis Peternakan di Indonesia. Prosiding Seminar Nasional Komunikasi Hasil-Hasil Penelitian Ternak dan Usaha Pengembangan Peternakan dalam Sistem Usahatani Lahan Kering di BPTP Nusa Tenggara Timur, Waingapu, Indonesia. 23-24 Agustus 2004, hal. 464-484.

10. Suryana (2009). Pengembangan Usaha Ternak Sapi Potong Berorientasi Agribisnis dengan Pola Kemitraan. Jurnal Litbang Pertanian. Vol. 28, No. 1, 2009, hal. 29-37.

11. Syamsu, J.A., Sofyan, L.S., Mudikdjo, K., dan Sa'id, E.G. (2003). Daya Dukung Limbah Pertanian sebagai Sumber Pakan Ternak Ruminansia di Indonesia. Jurnal Wartazoa. Vol. 13, No. 1, 2003, hal. 30-37. 